\title{
在中國科學院学部成立 大會上的報告
}

(1955 年 6 月 2 日)

郭 沫 若

委員郡、來賓僻8

中國科学院要設置学部, 分工進行科学工作的具体領導, 經过一年的簽储現在正式 成立了。在目前的情况下, 我們設置 4 個学部, 即物理学教学化学部、生物学地学部、 技術科学部和哲学社会科学部。这是我國科学事業發展中的一件大事。从今天起, 23:3 位 学部委員, 中國優秀的科学家, 要更有組織地參加中國科学事業的領導工作了。这二百 多位学部委員在科学工作中是有成就的, 具有丰富的尌門知識, 站到領洋工作的阙位.上 來, 就可以了解和研究科学工作中各方面的閶題, 提出宝贵的意見, 使得忡國科学院的 机能大大加强, 能够滕任愉快地担負起在國家建設中所接受的崇滈任敢。各学部的委其 們今後将有許多称常工作要做，而在这次会議上，我們的主要任務就是要來研究第一佔 五年計劃期間中國科学院的工作網要, 研究如何改淮中國科学院的工作以推動全國科学 事業没展的办法。荬現在想简略地報告一下当前我國科学工作的情况, 提出一些意胃, 䍀 各委員們討諭。

我們祖國正在進行着偉大的社会主義建設，正以大力本提偪工農業生流、实現國家 的社会吉義工業化，並促淮國防的現代化。舀了勝利地完成这些任務，必須充分地利用

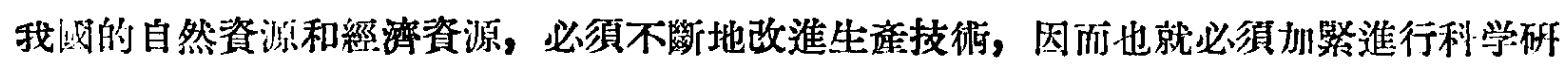
究工作。同㭙，在社会主義改造事業中，在交化建設和思想鬥孚中，也一定裂淮行一系 列刻苦的科学研究工作，才能勝利地完成任務。經驗証明：由於缺乏充分的科学根暴的 原故，不少工作不得不帶有宣目性，因而遭受到損失。幾年來觉和政府一面是關心利科 学工作的盓展的。在科学研究机構的調整和充实方面, 在研究方啮的改淮和指導方面,

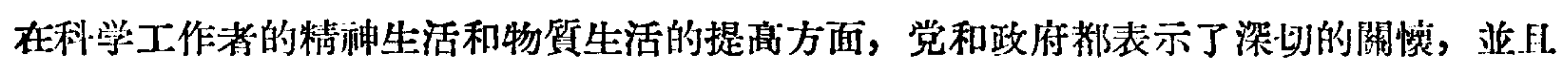

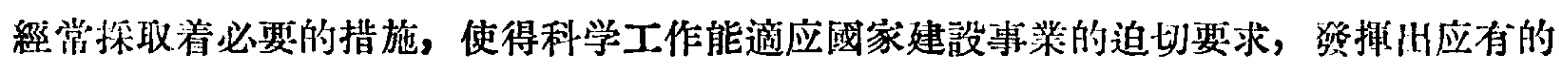
作用。

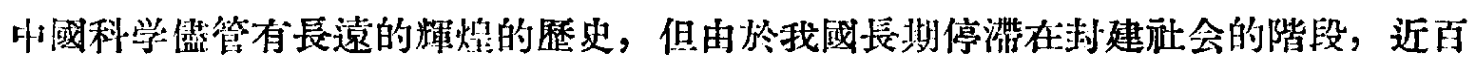

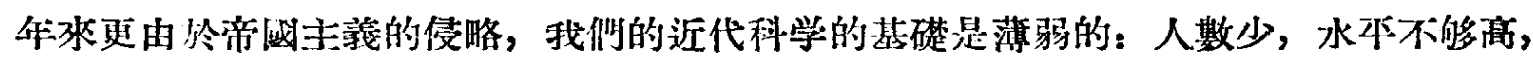
發展不平衡, 不能滴应就会主義建設的需要。如果我們不急起㨁追, 到了芳平年之後, 
科学工作仍然会落在後面，那对网家建設是会發生很不利的影响。世界已縕進入了原于

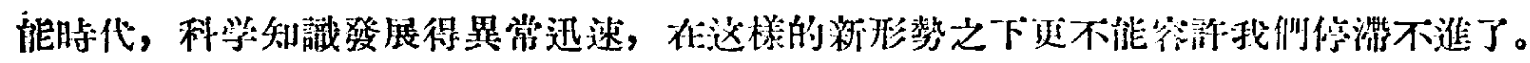

在:党和政府的深切關懹下，中國的科学事業自建國以來有了不少的改進。首先是科

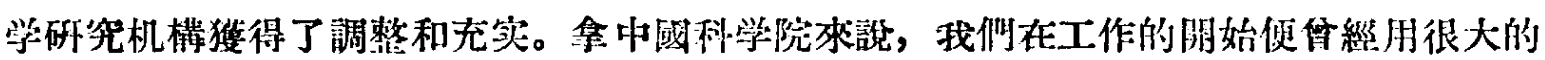

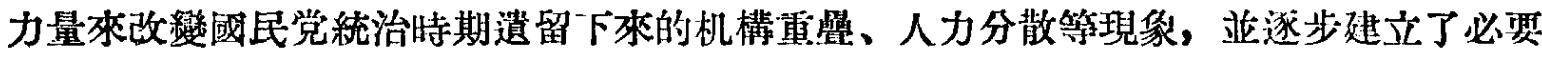
的新的研究机構。到目前篇此, 中國科学院研究單位比 1950 年㘿加 1.4 倍, 研究人員州 加 4 倍多。此外，政府各部阿所屬的研究單位和研究人員也有很大的發展。1954 代到 1955 作学年初全國高等学校維过院系調整之後，科学研究工作已經初步渡開了。

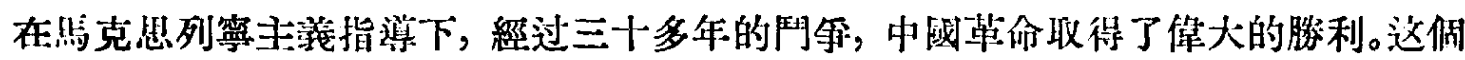
偉大的歷史事实敎育了中國人比，也教育了中國科学家。中國人民包、中國科学家以有中

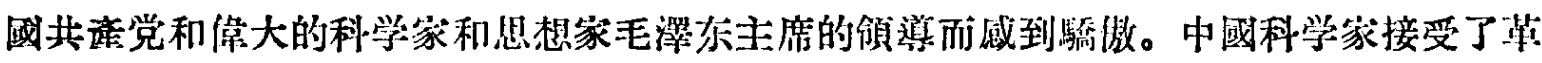

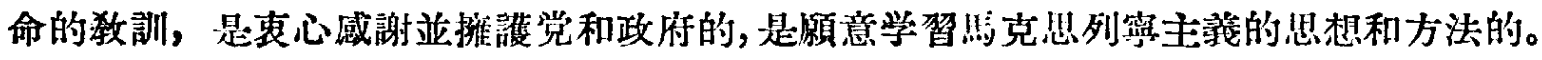
解放以來，我佃一㨁在䧟照毛主席的指示，淮行着思想改造的自我教有。特別在 1952 作

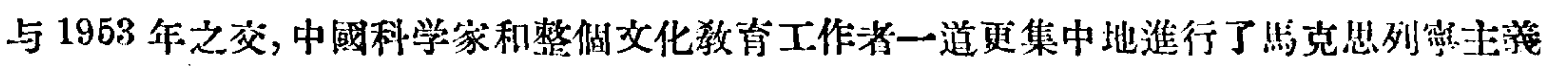
的学晳, 使理淪联系实際, 努力改沿自己並改進工作。

䋥过自我敉育傕動的結果，中國科学家們在思想上的進步是很顯著的。政治觉悟州 深了，工作熱情提高了，除掉極少数人外，都愿意和國家建設密切配合，做出成綪将傜 人民服務。1952 年在反对美帝國主義進行細菌战的鬥爭中，解多科学工作者到朝鮮前線 和朝鮮科学工作者一道淮行了忘我的工作而獲得勝利, 是一咨出的表現。西藏和本解放

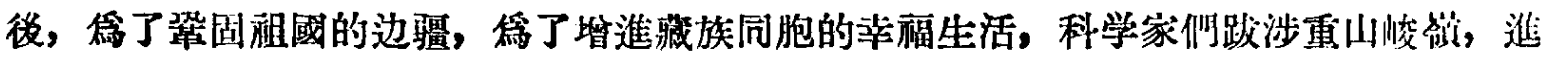
入西藏進行自然和社会的調查陑有所創獲, 是又一突出的表現。絶大多數的科学傢已櫂

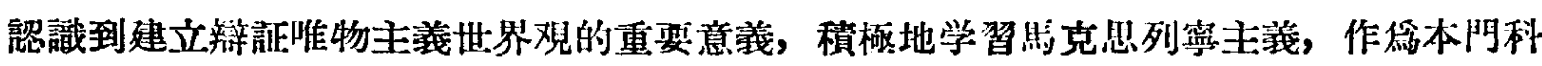

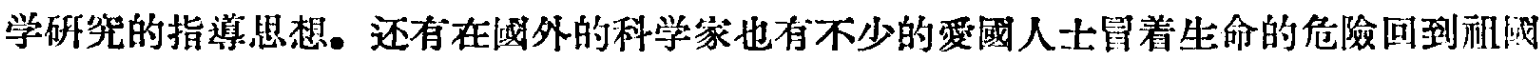

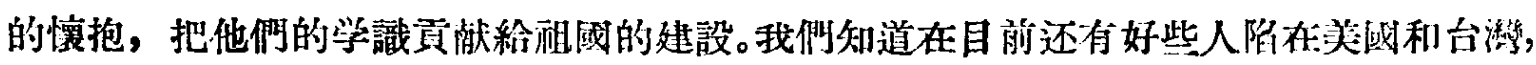

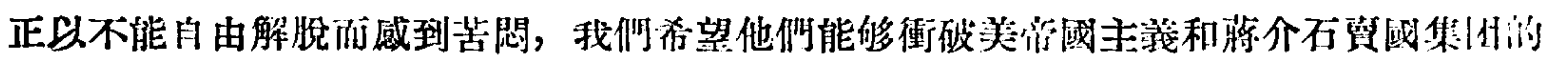
封鎖，回到人民的榢伍寒來。

科学研究机構經过必要的調整和充实,科学家的思想和研觉方法地有了斯㵔的改進,

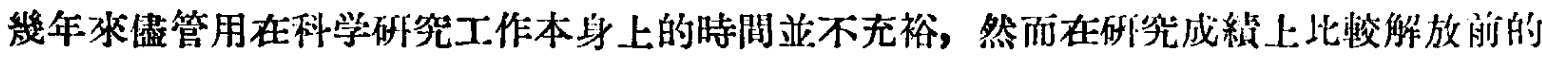

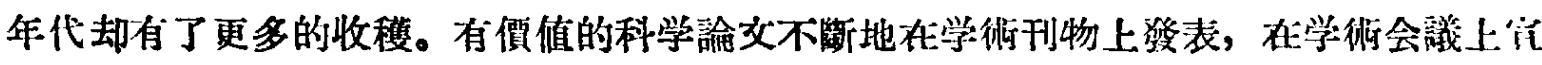

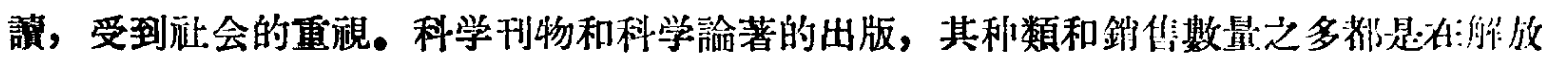
前所不能萝想的。在自然科学方面, 數学、物理学、化学、生物学、地学馟防域中都有 新的創見, 对於淮一步的研究工作具有重大的意義。还有一部分研究成果在成家建設中

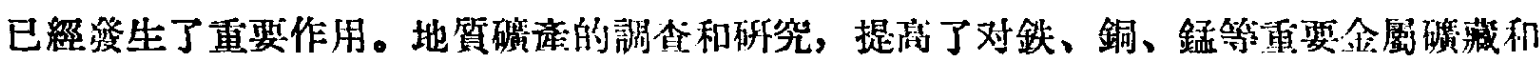

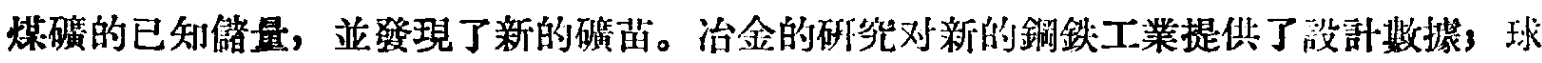

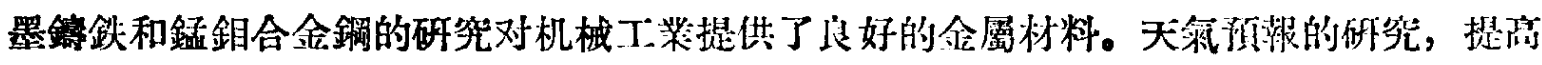

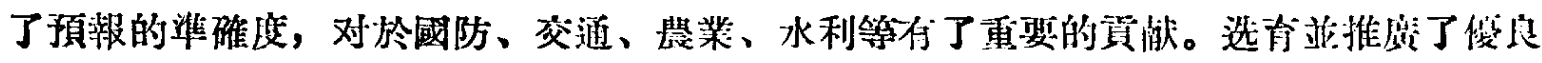

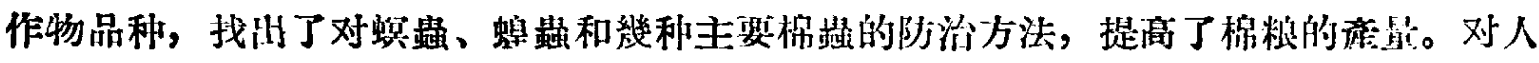
民保健事業有重琴關係的抗生素的綜合矿究也取得了重要的成綪。此外，關於士珤、 


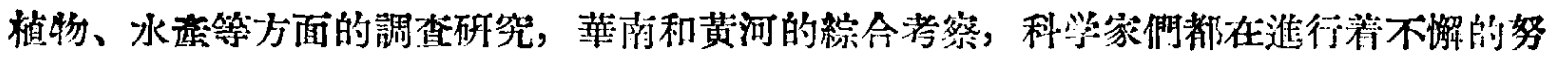

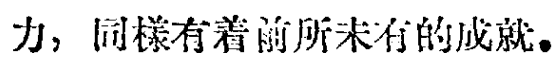

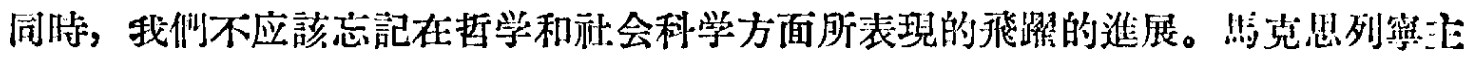

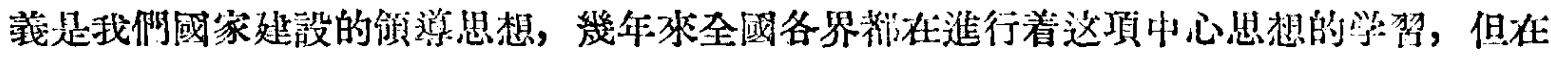
这裹必須特別提到的是从去年 10 月開始的对胡適、湖風等反動想想批制的展阙。对於这 一思想鬥乎，牛年多隶，許多学術工作者發表了不少的論文，進行了不少次的菲演。中

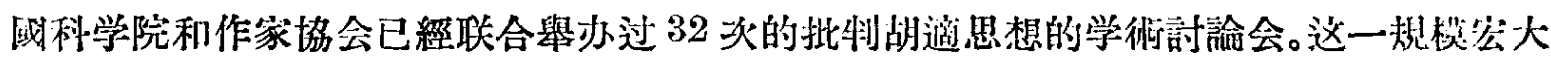

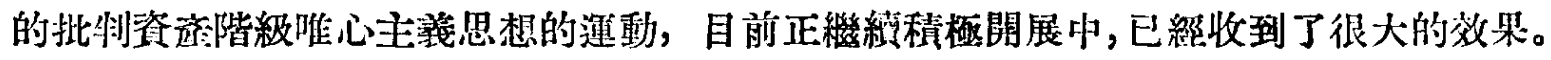
遁过对反動思想的批判，我們具体地学習和運用了馬克思列寧主㼁。特別芫强發了二十 多尔來潛藏在草命陣營寒面進行反党、反人民、反革命的胡風集团，更提的了各界人民

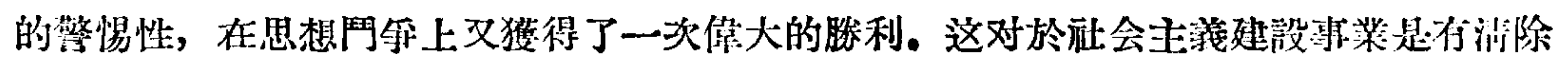
㜔礙的作用的。

我們許多科学研究成精的獲得是和学習苏联先進科学分不開的。在过去幾仵中，科

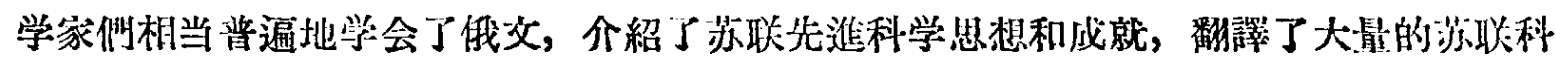
学著作, 对提高我國利学水平起了相当大的作用.

幾年來受國的科学家們在科学研究上的成就是应該肯定的，科学的方面多，成精地

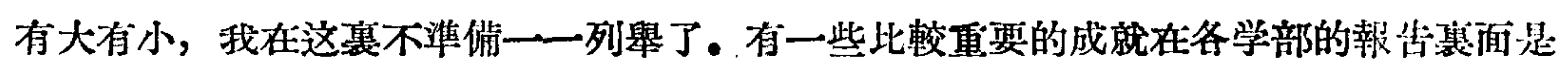
会有更詳細的說朋的。

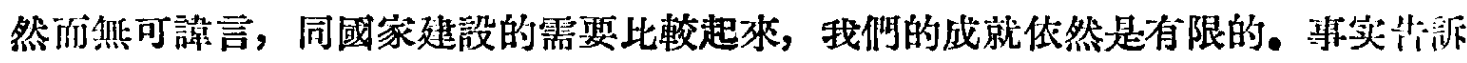

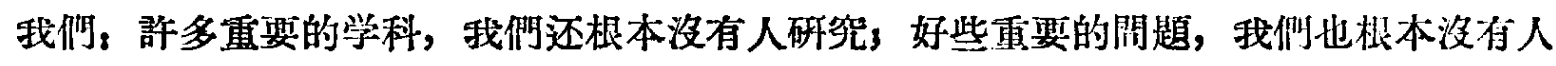

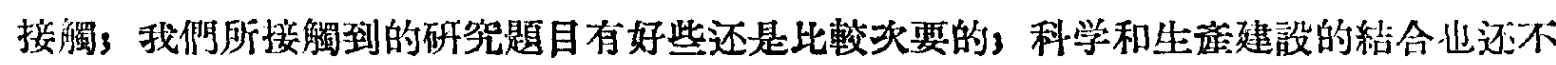
那朒緊密。当然, 我們知道, 科学研究是高度複雜的胉力勞動, 重要的研究成果不是短時 期內可以得到的，往往要費十年八年，或甚至更多的年月。因此，關於这一層，我何留 特別希望在產業部門担負实際建設的同志們能有深切的諒解。特別是科学成果烈見詴应 用, 那还需要善業部門和呼究部門作一番共同努力才能办到。但我們科学家們也不能的

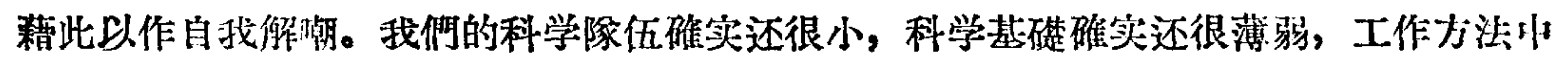
应該改正的缺點確实还很多，而科学任務却又十分艰巨，我們是沒有絲毫理由可以允許 自滿的。

中國科学院是組擮並領導科学研究的中心机構, 当然不能推卸掉自己所应該担负的 很大的責任。中國科学院幾年來在組織科学家傜國家建設服㹢方面, 不能否認, 是作了 不少工作，也取得了一些成績。但是所存在着的缺點確是很多，特別在院的領䈍工作方 面。

我們应該承認：科学院領旉工作中最主要的一個缺蚛，就是沒有認與研觉四家建設 的需要，來制定科学發展計劃; 推進㧴國科学事業。我們和政/作各部門的联系是很不佝 的, 政府各部門对於科学研究工作的要求我們不很清楚。近代各門科学發展的現狀和我 或科学工作者的管在力量, 我們也不很清楚。㨁到現在, 我們还没有提汕过一倜科学發

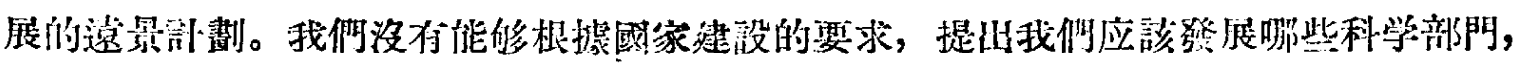

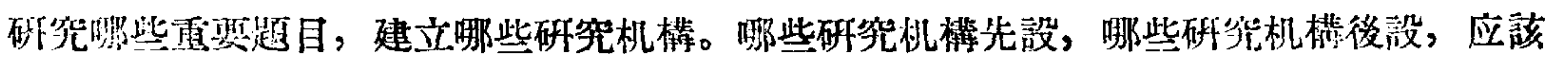
7 月号
科学邀報

- 9 - 


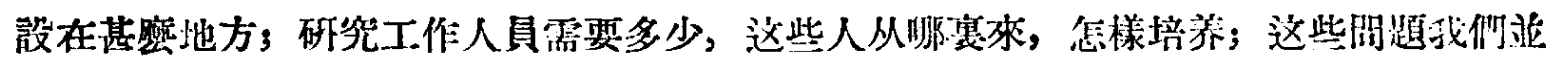

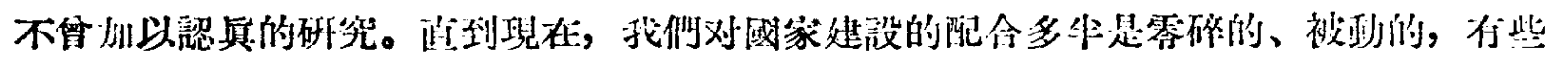
最重要的研究部門和研究项目反防被忽悓了。侧如地筫科学的發展对於工栄建设具有决

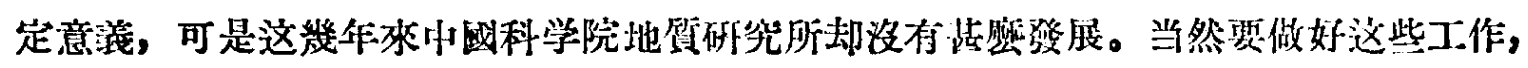
不是沒有客观困难的，但我們的主覌努力不能是撉供疑間的。

立分墢揮科学家的皘極性和創造性, 是科学院領導工作中一個重要的任陊。党和政 府一再指示我們必須依靠科学家來做好科学工作, 必须正確地執行团結科学家的政策。 可是, 正是在这個根本問題上, 我們的工作是不能令人㴖意的。近刚年冰这方面的工作

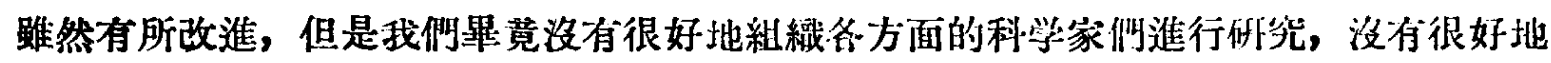

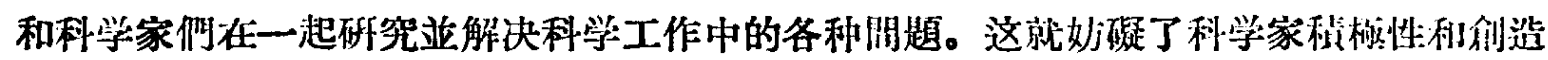
性進一步的發揮。我國的利学水本，一般說隶，是比较低的，但也必须不到，我國俊秀 的科学家证不在少數, 有多數的科学家也具有相当的水本, 而且也在不斷的提甬当川。

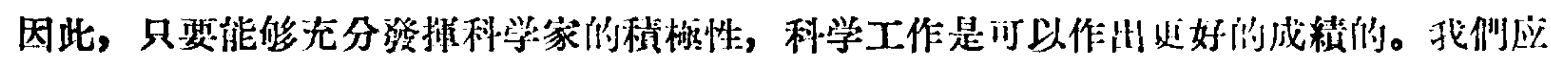

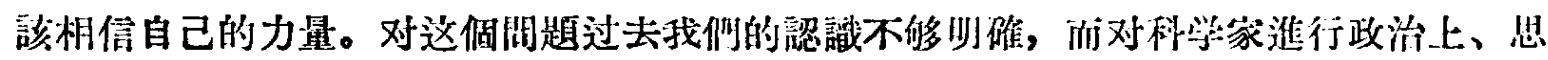
想上的督助工作, 也進行得不够, 这就不能不影响到科学政究的成就。

科学院的任務敃是組織和領導研究工作，除了妿做好一般的政治思想领望和做好行

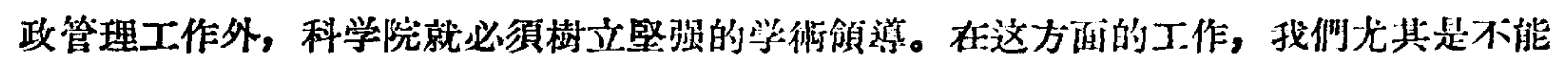

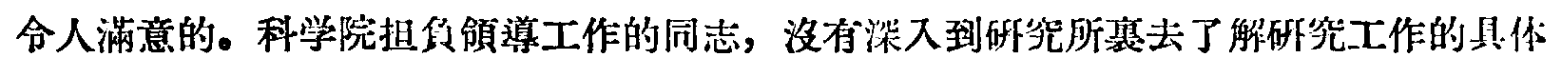
情况, 自己没有進行科学研究. 因此, 对各研究所工作的方晌、重涢研究題目、研究力 量的組糡、研究工作的指導思想，我們美不多常常是沒有能够及時地提纳意見，探取必

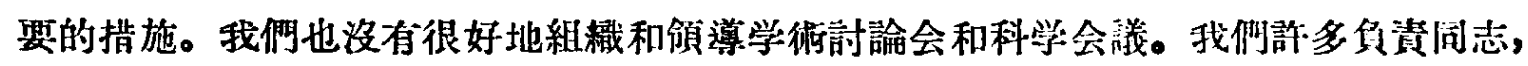
忙於開会、批公交和处理日常行政事務，而对於学猃領望却洼意得不够。

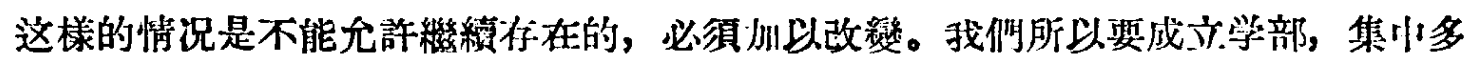

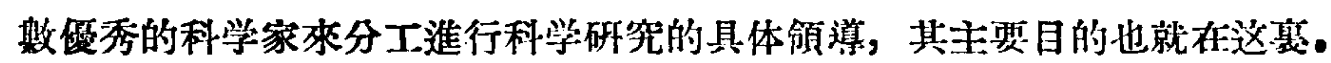

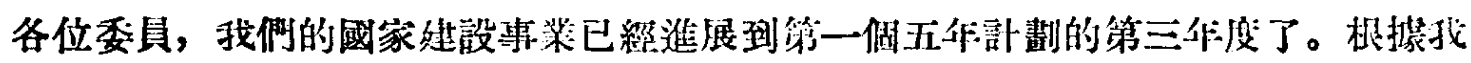

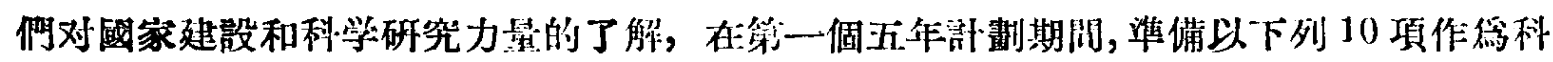

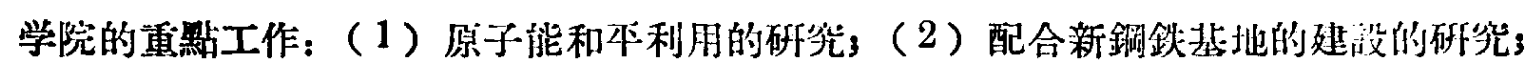

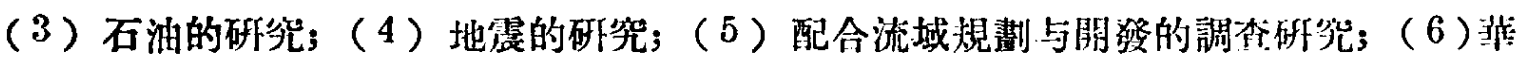
南熱带植物资源的調查研究; (7) 中國自然區劃和縃濟區劃的䂧究; (8) 抗生素的研 究3（9）我國过渡時期國家建設中的各种基本理論閣題的研究了（10）我國近代、現代 史和近代、現代思想史的研究。这些重默工作大部份已經在進行当中，中國科学院应該 集中更大的力量隶做，同㭙还必須組織全國各方面的科学研究力悬共周州緊完成任務。

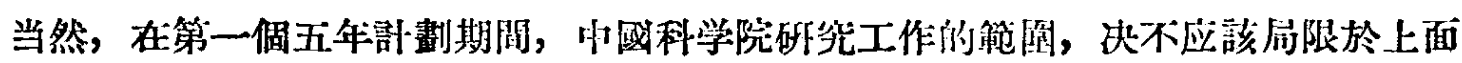

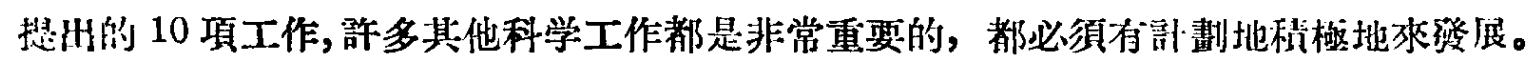

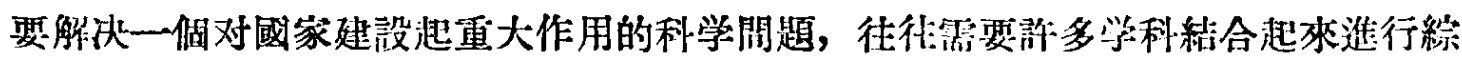
合性的研究。以往我們对於这种工作不够重視，今後必須了以加强。䍃此，中國科学院

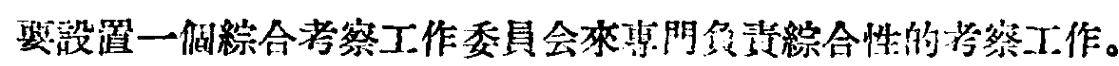




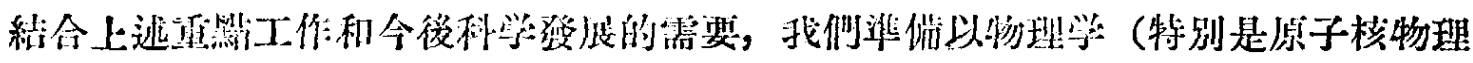

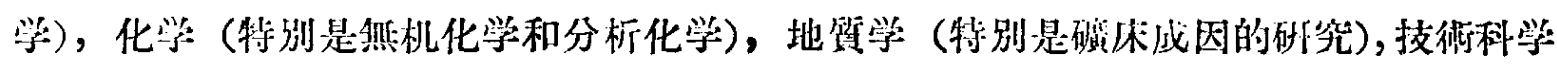

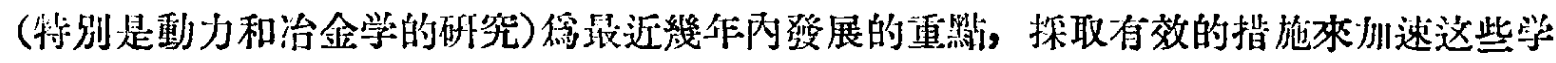
科的發展。馬克思列蜜主義的梅学和經濟学也应該大力發展。

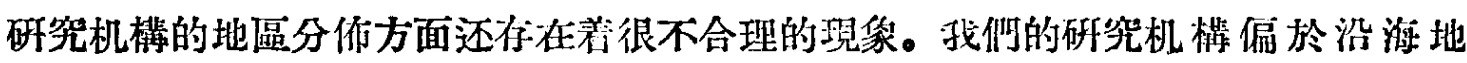

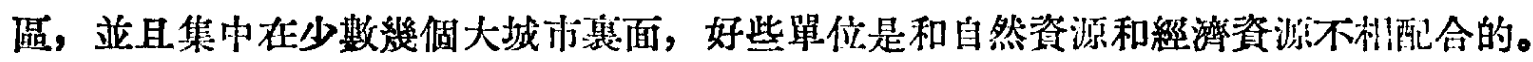

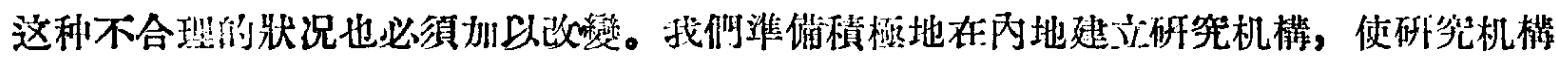

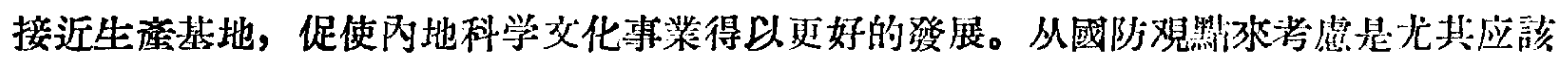

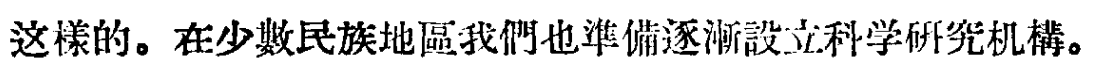

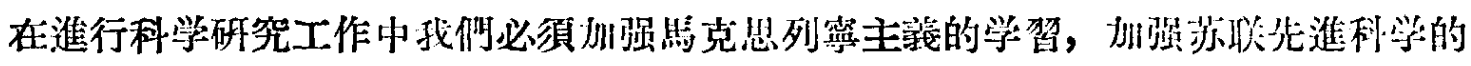

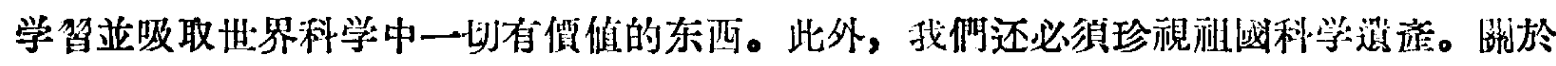

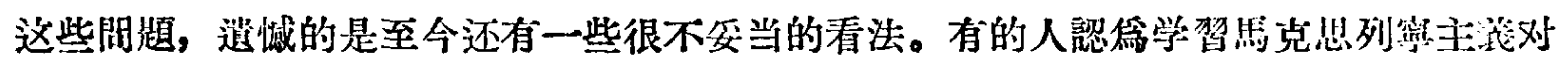

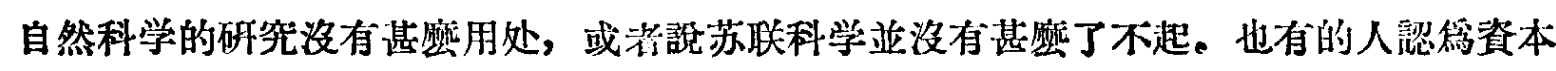
主㼁國家的科学成就应該根本抛菜。这些都是錯誤的見解，是应該加以改正的。祖國許

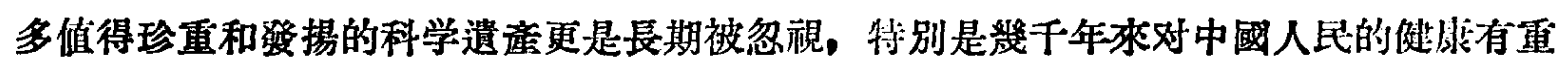
夫貢献的中國医藥知識被一部分衛生工作人員視舀“封建医”，而蓄意加以治娍，这和十

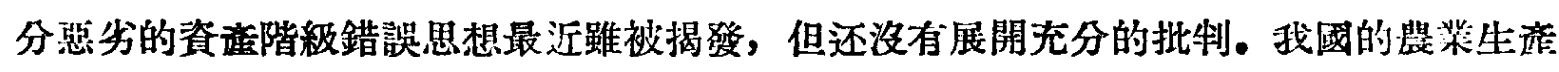

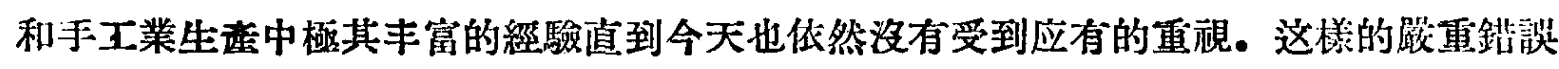

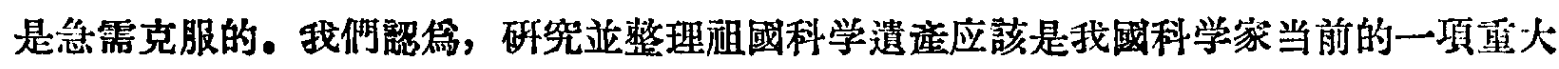
任務。

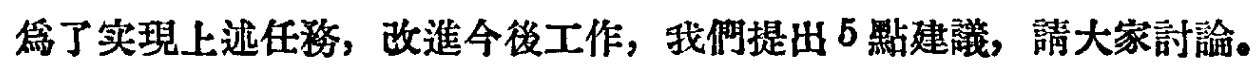

\section{一 加强科学工作的計劃性、研究並制定我國科学發展的遠量計劃}

我國科学工作必須有計劃地進行。國家大規模的建設倳業是長遠的, 科学家的培养 和科学成果的收穫也都需要相当長遠的時間。一般谽來, 由一位刻苦努力的大学畢婪生

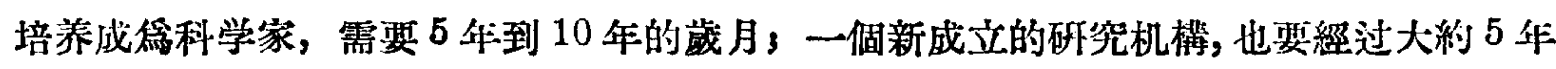
的時間才能捉供有價值的科学成果。因此, 科学發展的遠景計劃就尤其重要。只有有了 莩景訫劃, 才能够正確地安排今天的工作。

幾年來，中國科学院的研究工作是逐步向有計劃性方面發展的，在部劃工作上也初 步皘累了一些經驗, 但是科学計劃工作还是很落後的, 今後必須加强。

在制定計划時，理渝与实際的密切結合是必須遵行的原則。忽視这一原則，不䄊基 考慮國家建設的需要, 强調個人的興趣, 在任何時候都是不应該的。但我們决不能認媱 科学工作的任務就只限於解决眼前的閂題。大体說來, 科学院主要的应硋是研究基本的

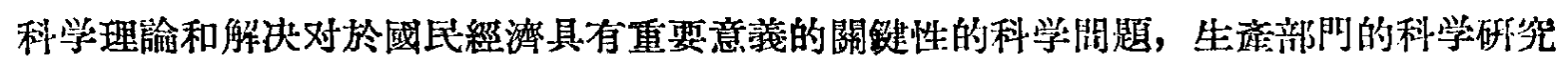
机满主要的应当解决生産中的实際技術閒題, 高等学校的研究部則根庴其具体條件研究

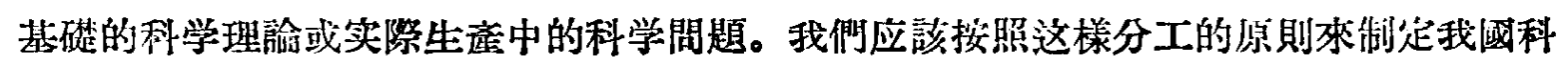
学䋁展的遠量即劃。 


\section{二 充分發揮科学家的力量, 皘極培苏新生力量}

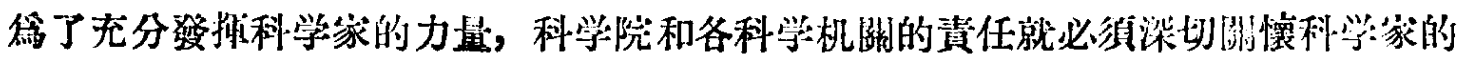

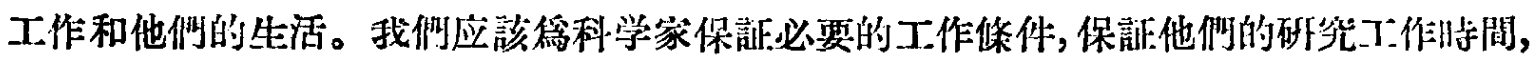
解决他們在工作中进到的各种困难。同時，我佃也应該使科学家了解我储的國家罗集中 主要的力量完成主要的任務，因此，生活水平的提高、工作條件的改善是有一定的附位

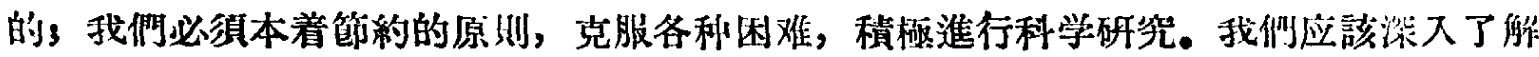

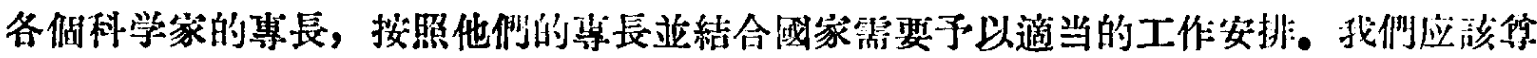
重科学家的尃門知誡和他們的辛勤勞動。我储应該在政治上、思想上關心他們的進步，

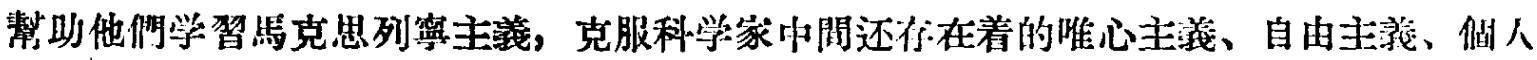
主㼁、宗派主㼁等等錯誤思想。

大力培养科学研究的新生力量, 以壮大科学工作的隊伍, 是㻐展我國科学事業、保

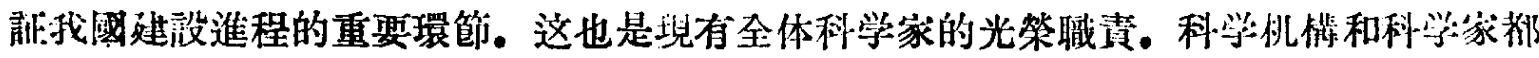
必須卜分重視这项工作。科学机構和高等学校应該建立或健全䂰究生制度，刘桨作科学 工作人員訂出培养和㡭級的办法。青年科学工作人員的研究成果必須加以重視，待利学

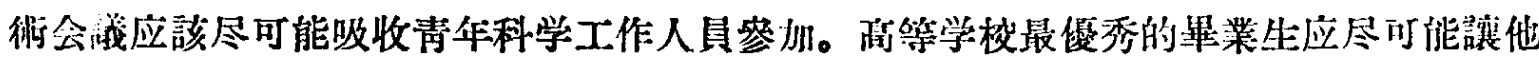

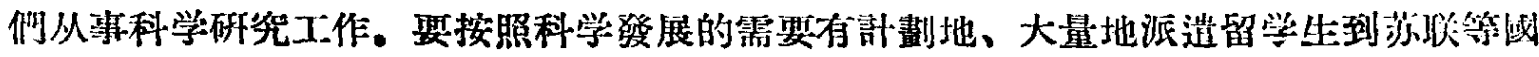
家学習。篇了实現这些任務，我們擬定了一愐“中國科学院研究生暫行條例 (草案)”提交 本次会墥討論，修正後將呈請上級批准、实施。此外，科学院还将設谓科学翰部培养部

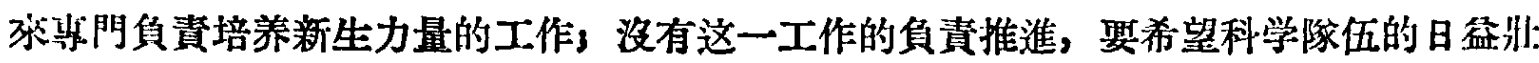
大是不能設想的。

\section{三 建立学位制度、院士制度和学術獎属制度}

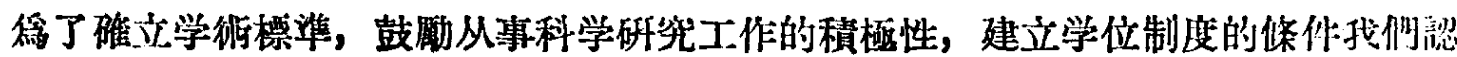

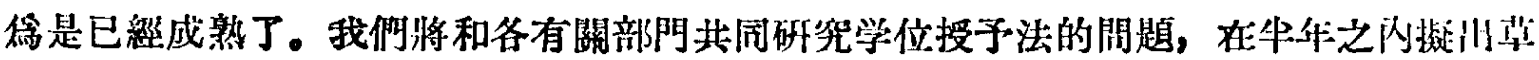
系，以便國家制定法律，並根據法律授予具有一定学街水本和成就的科学家以学位。“小

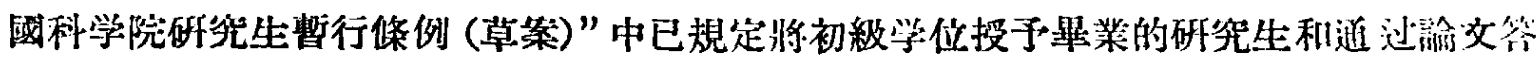
辩要查合格的科学工作人員。这個條例在獾得法律效力後, 即可实施。

科学院是科学家的組織。發提科学民主最好的形式就是院士制度、蛁以院士大会俘 科学院的最调机關的制度。我們也將和有關部門草提關於院士制度的法徘, 經过批准後,

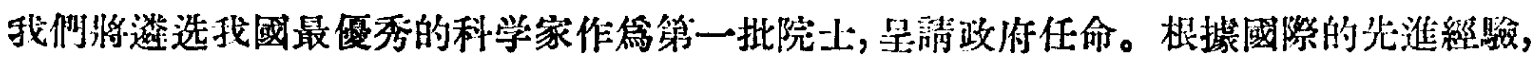

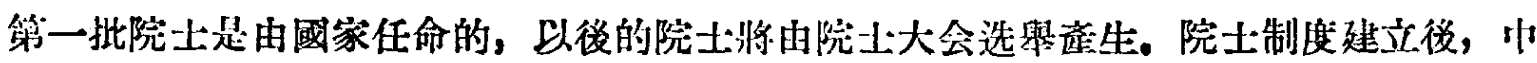

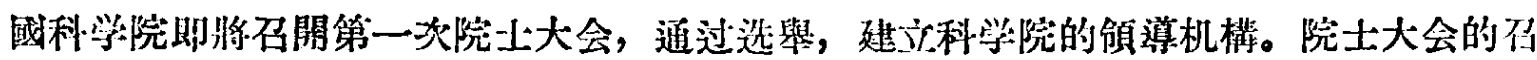

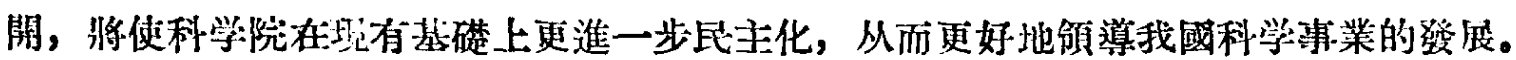

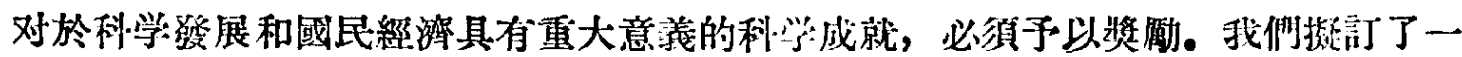

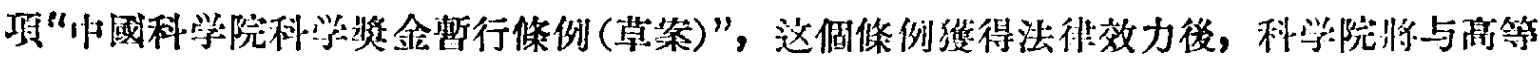

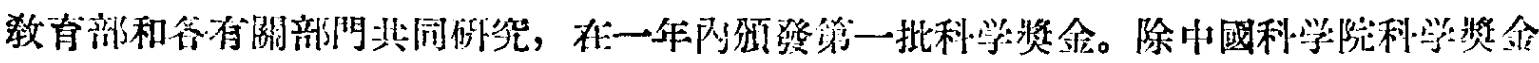

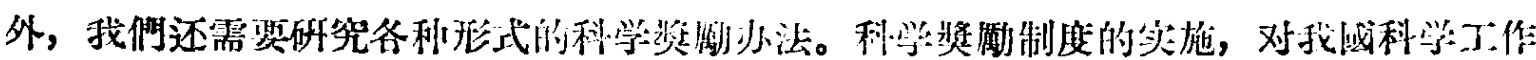




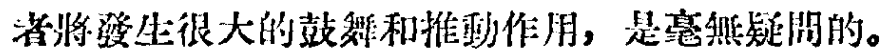

\section{四 加强國際間的科学合作}

加强國際間創造性的科学合作是我佃迫切的需要，也是苏联和各人民民主國家的共

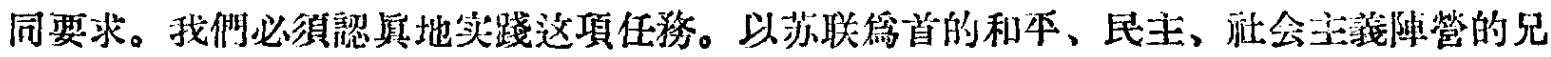
弟國家问在第克思列寧主義的雄幟之下，从事着共率主義和注会主義的建設，在好些科 学工作的計劃上，一定琹取得密切的配合; 不少的科学開題，要進行協同的研究; 各种

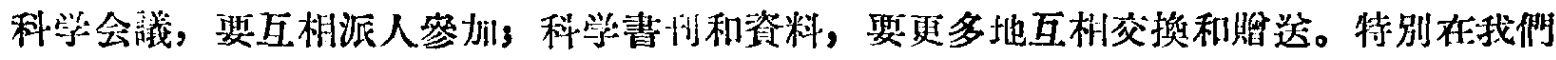

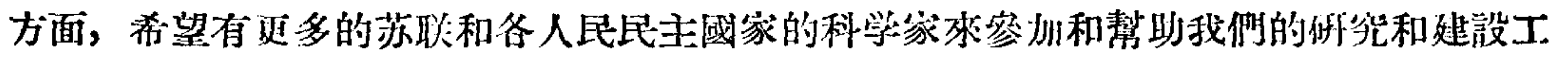
作，闹時也要不斷地愈來愈多地派遗我們的科学工作渚到兄弟國家去学習。过去，这方

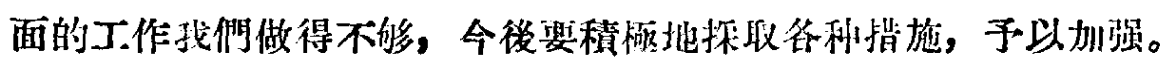

我們也要加强和其他國家特別是亞非國家科学家之閂的联系和合作，艾流䋑驗，相 互協助，俘促淮科学進步和維護世界和本校共同努力。

\section{五 加强学術領導}

我們有必要反覆地說: 科学院的領導工作是必須改進的, 而改進科学院領尊工作的 關舒建期在於加强学術领導。我們今天成立四個学部, 目的也就在这裹。中國科学院各学 部的重要任務之一，就是根㹉國家建設的需要和科学墢展的規律，根據我國的現狀，制

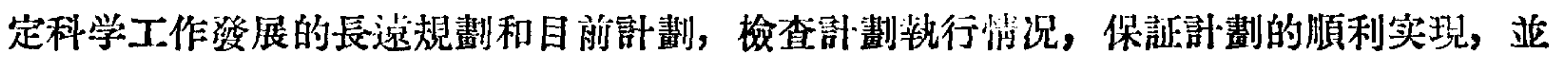
且、根據情况的發展, 在实踐中改進計劃。同時, 各学部还有督任組織全國的科学力量,

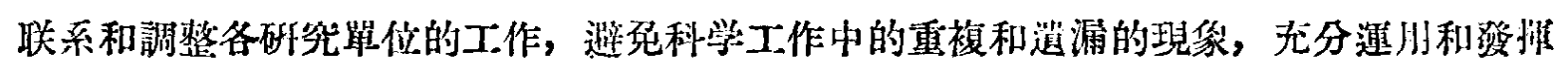
各骂位的特長，将分散的力量集中起來，用以解决國家建設的重要的任務。

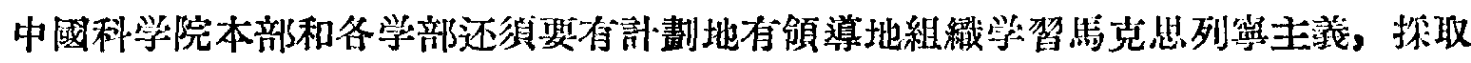

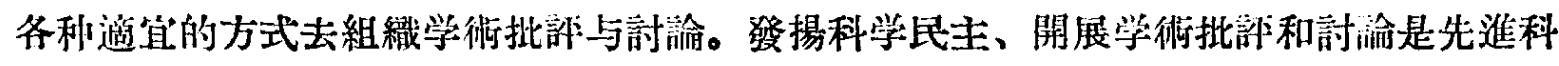

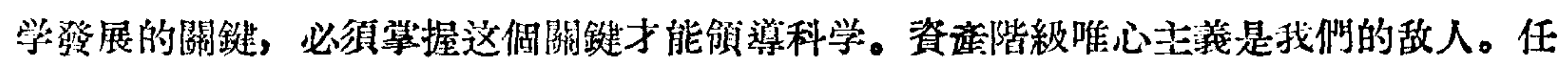

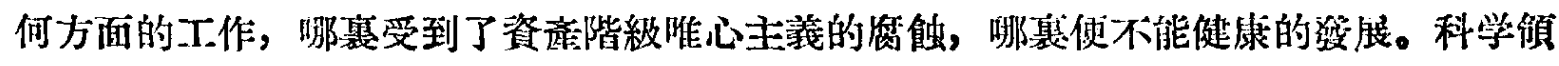

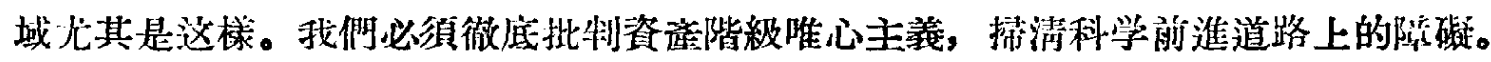

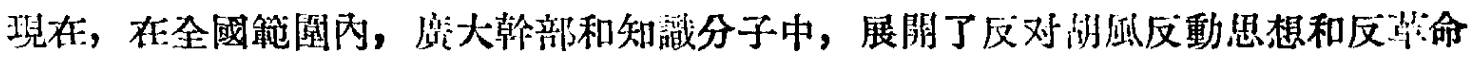

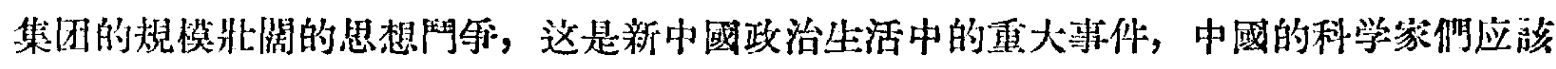

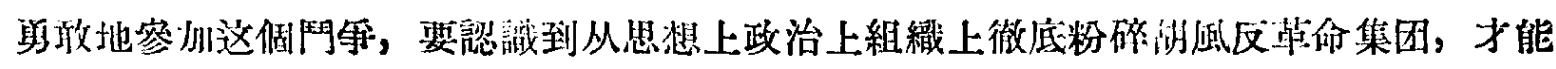

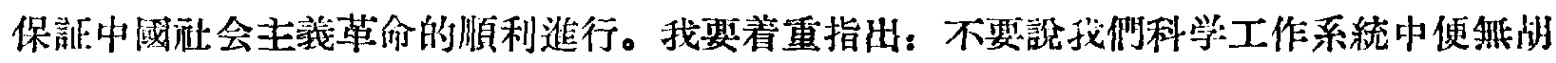
風分子或数似湖風分子，这种想法是完全錯誤的，要知道反革命分子的破烄是無孔不入

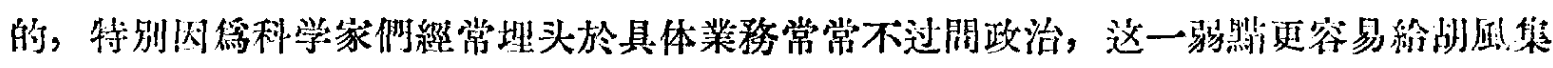

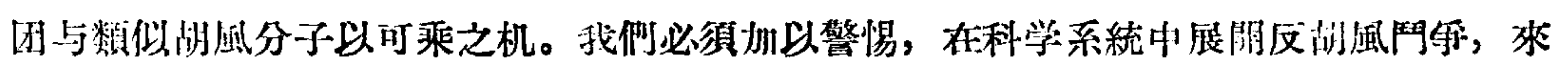

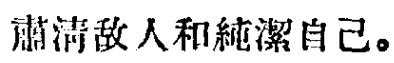

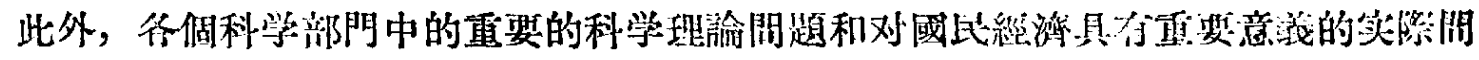

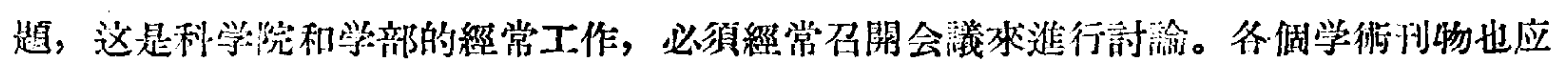

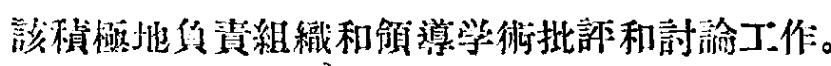




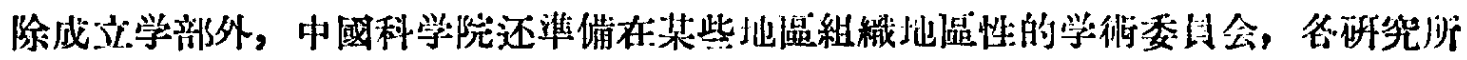

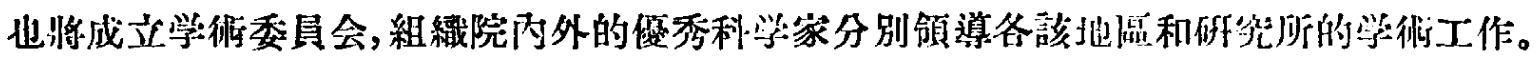

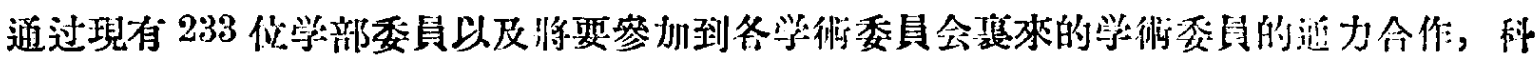
学院瓷䊈疑開地将大大改淮它和全國科学界与業部門的联系。

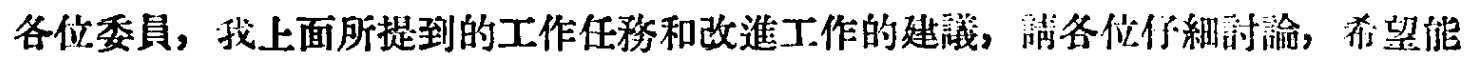
够得到修正和補光。

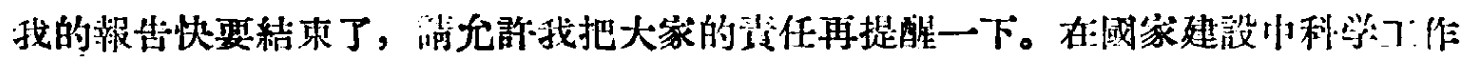

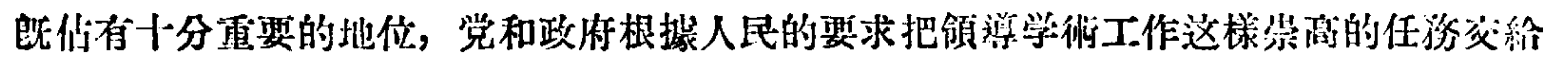

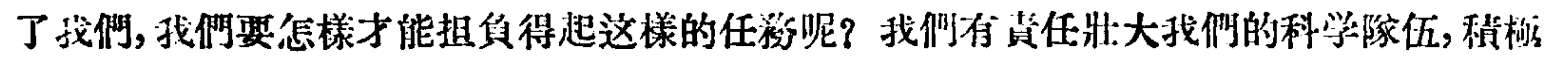

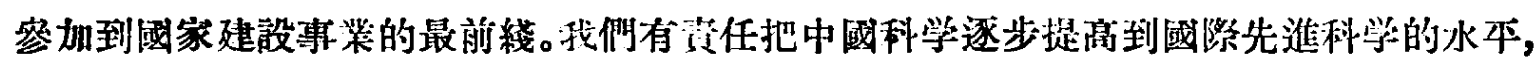

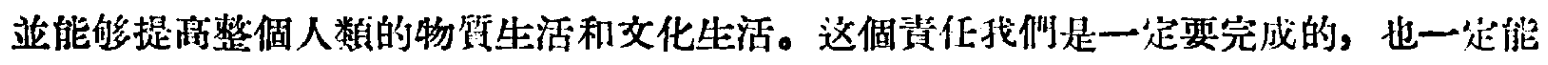

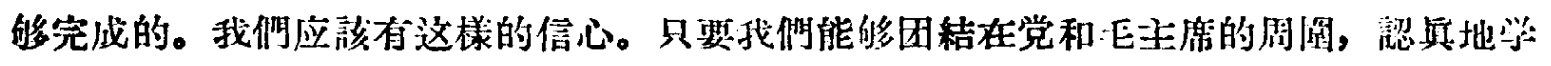

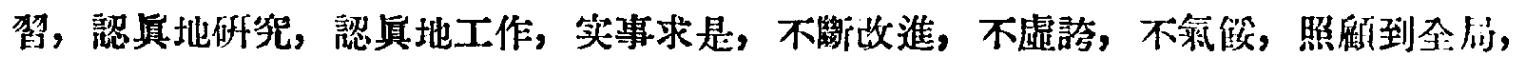

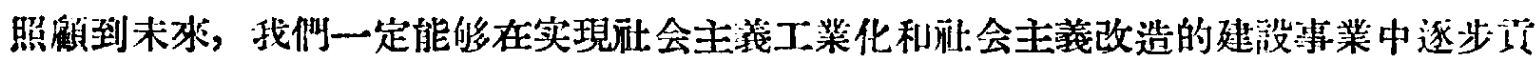

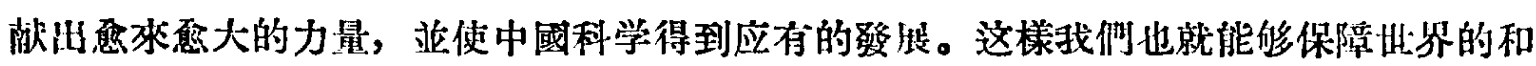
本和人類的幸福。

祖國的前途是無限光明的, 科学的前途也是無限光明的.

讓我僻在馬克思列寧主㼁的旗幟之下膯利前進! 